\title{
Urinary Incontinence Severity, Depression and Anxiety Relation in Osteoporosis Patients
}

\author{
Osteoporoz Hastalarında Idrar Inkontinansı Şiddeti, Depresyon ve Anksiyete ilişkisi \\ (1) Ejder Berk, (1) Sema Baykara* \\ Sütçü Imam University Faculty of Medicine, Department of Physical Medicine and Rehabilitation, Kahramanmaraş, Turkey \\ *FIrat University Faculty of Medicine, Department of Psychiatry, Elazı̆̆, Turkey
}

\section{Abstract}

Objective: The present study aimed to analyze the relation between urinary incontinence (UI) severity and depression, anxiety and quality of life in osteoporosis patients.

Materials and Methods: Based on the bone mineral density (BMD) measurements conducted on the lumbar vertebra and femoral neck regions with dual-energy X-ray absorptiometry, those with BMD values between -1 and -2.5 standard deviation (SD) were considered as osteopenia patients $(n=39)$, those with -2.5 SD or higher values were considered as osteoporosis patients $(n=37)$, and those with BMD values lower than -1 SD and without any disease history were determined as the control group ( $n=37)$. Socio-demographic data form, Incontinence Severity index (ISI), Quality of Life scale (SF-36), Beck Depression inventory (BDI), and Beck Anxiety inventory (BAI) were applied to all participants.

Results: It was determined that there were significant differences between the control group and the osteoporosis group, and between the osteoporosis group and the osteopenia group based on ISI scores, which was higher in the osteoporosis group. As the ISI score increased, $\mathrm{BDI}$ and BAI scores increased as well. There was no correlation between ISI score and quality of life subscales.

Conclusion: $\mathrm{UI}$ is a common condition among osteoporosis patients and the severity of $\mathrm{UI}$ increases with a decrease in BMD. Both osteoporosis and UI could lead to high level of depression and anxiety. The investigation of the presence and severity of UI, questioning of the depression and anxiety in osteoporosis patients would contribute to the management of the disease.

Keywords: Osteoporosis, incontinence severity, depression, anxiety

\section{$\ddot{O z}$}

Amaç: Osteoporozlu hastalarda üriner inkontinansı (Üi) şiddeti ile depresyon, anksiyete ve yaşam kalitesi arasındaki ilişkinin değerlendirilmesi amaçlandı.

Gereç ve Yöntem: Olguların dual enerji X-ray absorbsiyometre yöntemiyle lomber vertebra ve femur boyun bölgelerinden yapılan kemik mineral yoğunluğu (KMY) ölçüm sonuçlarına göre, KMY değerleri -1 ile -2,5 standart sapma (SS) arasında tespit edilenler osteopeni ( $n=39$ ); $-2,5$ SS ve yüksek değerler Osteoporoz ( $n=37)$, KMY değerleri -1 SS'den düşük ve herhangi bir hastalık öyküsü olmayanlar kontrol grubu $(n=37)$ olarak değerlendirildi. Tüm katılımcılara sosyo-demografik veri formu, İnkontinans Şiddet indeksi (işi), Yaşam Kalitesi ölçeği (SF-36), Beck Depresyon envanteri (BDE) ve Beck Anksiyete envanteri (BAE) uygulandı.

Bulgular: Gruplar arasında işi açısından kontrol grubu ile osteoporoz grubu arasında ve osteoporoz grubuyla osteopeni grubu arasında, osteoporozlu grupta yüksek olacak şekilde, anlamlı farklılık vardı. işi skoru artııç̧a BDE ve BAE skorları artmakta idi. işi skoru ile yaşam kalitesinin alt ölçekleri arasında ilişki saptanamadı.

Sonuç: Osteoporozlu hastalarda Üi sık görülen bir durumdur ve KMY azaldıkça Üi şiddeti artmaktadır. Hem osteoporoz, hem Üi yüksek oranda depresyon ve anksiyeteye neden olabilmektedir. Osteoporozlu hastalarda Üi varlığı, şiddeti, depresyon ve anksiyete durumunun sorgulanması, osteoporoz yönetimine katkıda bulunacaktır.

Anahtar kelimeler: Osteoporoz, inkontinans şiddeti, depresyon, anksiyete 


\section{Introduction}

Osteoporosis is characterized with the increase in bone fragility and fracture probability as a result of low bone mass and deterioration of the bone tissue. Based on the values obtained with dual energy X-ray absorptiometry in young adults, the vertebral or hip bone mineral density (BMD) between -1 and -2.5 standard deviation (SD) is considered osteopenia and a BMD of over 2.5 SD is considered osteoporosis (1).

Osteoporosis incidence is $30-50 \%$ among females and $15-30 \%$ among males (2). Osteoporosis incidence increases with age. The prolongation of the average human life increased the adverse effects of osteoporosis and complications associated with osteoporosis on quality of life (3). Urinary incontinence (UI) is the case of involuntary loss of urine that could be objectively demonstrated and leading to social and hygienic problems as defined by the international continence society. It is more common in women when compared to men. The UI incidence is $3 \%-11 \%$ among males, while the rate is $10 \%-58 \%$ among females.

Its prevalence increases with age (4), however it is not considered a physiological component of aging (5). $\mathrm{UI}$ is a condition that affects life negatively due to its physical, psychological effects and additional burden on the family budget. UI is associated with increased urinary tract infection incidence, sleep deprivations, falls, fractures, pressure ulcers. It leads to psychological and social loneliness a decrease in performance, anxiety, depression, impaired sexual functions, lower functional independence and increased burden for the caregivers (5).

Certain studies in the literature demonstrated that osteoporosis was associated with UI $(6,7)$. In a study conducted in an osteoporosis clinic, $67 \%$ of the patients reported one or more Ul-related symptoms, and $40 \%$ experienced one or more UI per week (8). Osteoporosis is associated with advanced age. The prevalence of $\mathrm{UI}$ is also known to increase with age (4). Studies demonstrated that once a week UI incidence was $21 \%$ among 65 years old or older individuals (9) and $40 \%$ among 90 years or older individuals (6). It is known that there is a correlation between osteoporosis and depression. Reduced mobility and pain observed in osteoporosis restrict daily activities of the individual, leading to isolation, negative effects on the mood, a decrease in self-confidence, and consequently a decrease in quality of life (10). Studies demonstrated that women with UI are more prone to depression and social isolation, experienced higher levels of anxiety and low self-confidence when compared to women without UI $(11,12)$. UI, which is a common condition in the elderly women population, is not brought to the agenda sufficiently since it is considered embarrassing by the patients and is attributed to aging.

The present study aimed to investigate the correlation between UI severity, depression, anxiety and quality of life in osteoporosis patients.

\section{Materials and Method}

After the present study was approved by the ethics committee of Kahramanmaraş Sütçü İmam University Faculty of Medicine (approval number-date:142-05.05.2019), 85 patients who met the study criteria, with BMD values of -1 or less, and who had no psychiatric diagnosis based on DSM-5 (13) were invited to the Physical Medicine and Rehabilitation Outpatient Clinic to participate in the study. Written informed consent forms were taken from all participants before the study. Patient interviews were conducted by physical therapy and psychiatry specialists. The patient inclusion criteria included age between 40-70 years, literacy, no Previous disease impeding neurological and psychiatric communications, and no Current Metabolic disease. Patients with osteoporotic compression fractures, patients with secondary osteoporosis due to hormonal dysfunctions such as Diabetes Mellitus, thyroid and parathyroid disorder, and patients with surgical menopause were excluded. Furthermore, five patients were excluded from the study because they did not meet the study criteria and four people refused to participate in the study for personal reasons. A retrospective scan through the hospital information system was conducted and patients with a BMD between -1 and -2.5 SD were included in the Osteopenia Group, those with a BMD of -2.5 and below were included in the Osteoporosis group based on the World Health Organization criteria (14). The control group included 37 patients, who applied to the Physical Therapy and Rehabilitation Outpatient Clinic without any psychiatric diagnosis or treatment history or any other previous Physical diseases and a BMD above -1 SD. Patient BMD values were measured with Hologic QDR 4500 (Bedford, MA) in anteroposterior position from lumbar vertebra (L1-L4) and left proximal femur during admission to the outpatient clinic. Body mass index (BMI), age, gender, lumbar vertebra T-score and femoral neck T-score data were recorded for all participants. Patient BMI scores were calculated by dividing their body weight by the square of their height $(\mathrm{m})$. All participants completed a semi-structured sociodemographic data form developed by the authors based on experience and information obtained with a literature review Incontinence Severity index (ISI), Quality of Life scale, Beck Depression Inventory (BDI) and Beck Anxiety Inventory. All procedures were conducted based on the ethical principles depicted in 1975 Helsinki Declaration of Human Rights (15) and by the human experiments committee (institutional and national) 2000 revision.

\section{Sociodemographic Data Form}

All subjects completed a sociodemographic data form developed by the authors based on experience and information obtained with a literature review and the study objectives. The semistructured form questioned sociodemographic information such as age, gender, marital status, education level, occupation, income level, and clinical data such as disease duration and number of hospitalizations. 


\section{Incontinence Severity index}

The scale was developed in an epidemiological study conducted on 28,000 women in Norway to evaluate the women who suffered from UI (16). It includes 2 questions about the frequency of UI (4 stages) and the urine loss volume (3 stages). Turkish validity and reliability study was conducted by Hazar et al. (17).

\section{Beck Depression Inventory}

It was developed by Beck et al. (18). The inventory aims to measure the severity of cognitive, emotional and motivational symptoms in depression. It is a 4-point Likert-type Self-report scale that includes 21 items. Turkish language validity and reliability of the scale was determined by Hisli et al. (19) The scale does not diagnose depression. The cut-off score is 17 .

\section{Beck Anxiety Inventory}

It was developed by Beck et al. (20). The 3-point Likert-type Self-report scale includes 21 items, is used to determine the frequency of anxiety symptoms that individuals experience. Turkish language validity and reliability of the scale was determined by Ulusoy (21).

\section{Short Form 36}

It is a Self-report scale with generic criterion property and was developed to assess the quality of life (22). A Turkish language validity and reliability study was conducted (23). It includes 36 items. The subscales include physical functioning, social functioning, role limitations due to physical health, role limitations due to emotional problems, emotional well-being, energy/fatigue, pain and general health. It is a Likert-type type scale except for certain items and the assessment was based on the previous 4 weeks. The subscales assess health between 0-100 and 0 indicates poor health and 100 indicates good health. It was reported that the subscales could be used to evaluate the quality of life in patients with Physical diseases (24).

\section{Statistical Analysis}

Data analysis was conducted with SPSS 22.0 software (IBM SPSS for Windows version 22, IBM Corporation, Armonk, New York, United States). Quantitative data were presented as mean \pm SD. Normal distribution of the collected data was examined with Kolmogorov-Smirnov test. Analysis of Variance spost hoc Tukey test and Pearson correlation analysis were conducted for independent group analysis. Data were analyzed at 95\% confidence level; a $p$ value lower than 0.05 was considered significant.

\section{Results}

The participants were categorized in 3 groups based on BMD scores: osteoporosis group (37 cases), osteopenia group (39 cases) and healthy group (37 cases). Patient age, m, weight, BMI, lumbar vertebra and femoral neck T-scores are summarized in Table 1. There was no significant difference between the groups based on age $(p=0.962)$ and BMI $(p=0.284)$ variables.

It was determined that there was no significant difference between the healthy group and the osteopenia group $(p=0.081)$ based on incontinence severity score, however there were significant differences between the osteoporosis group and the healthy group $(p<0.001)$ and between the osteoporosis group and the osteopenia group based on incontinence severity score, favoring the osteoporosis group $(p<0.001)$. The distribution of group incontinence severity scores is presented in Table 2 . As incontinence severity score increased, BDI $(r=0.505 ; p<0.001)$ and Beck Anxiety Inventory (BAl) scores increased as well $(r=0.316 ; p<0.001)$.

Table 1. Demographic characteristics of cases

\begin{tabular}{|l|l|l|l|l|}
\hline & $\begin{array}{l}\text { Normal } \\
(\mathbf{n = 3 7 )}\end{array}$ & $\begin{array}{l}\text { Osteopenia } \\
(\mathbf{n = 3 9 )}\end{array}$ & $\begin{array}{l}\text { Osteoporosis } \\
(\mathbf{n}=\mathbf{3 7})\end{array}$ & $\mathbf{p}$ \\
\hline Age (Year) & $61.68 \pm 7.69$ & $62.83 \pm 8.72$ & $60.05 \pm 10.19$ & 0.962 \\
\hline Height (cm) & $163.45 \pm 8.56$ & $162.88 \pm 9.36$ & $163.58 \pm 8.93$ & 0.312 \\
\hline Weight (kg) & $78.6 \pm 8.65$ & $75.34 \pm 9.67$ & $79.66 \pm 8.62$ & 0.322 \\
\hline BMl & $27.96 \pm 4.78$ & $28.34 \pm 3.96$ & $28.68 \pm 4.32$ & 0.284 \\
\hline Lumbar T score & $-0.64 \pm 0.57^{*}$ & $-1.85 \pm 1.39 *$ & $-3.25 \pm 0.71^{*}$ & $<0.001$ \\
\hline Femoral neck T score & $-0.61 \pm 0.35^{*}$ & $-1.57 \pm 0.82$ & $-1.62 \pm 0.85$ & $<0.001$ \\
\hline BMI: Body mass index; *: different form other groups (p<0.001) & & & \\
\hline
\end{tabular}

Table 2. Incontinence severity distribution in groups

\begin{tabular}{|l|l|l|l|}
\hline \multirow{2}{*}{} & \multicolumn{2}{|l|}{ Incontinence score } & $\mathbf{p}$ \\
\cline { 2 - 4 } & Mean & Standard Deviation & \\
\hline Normal & 1.70 & 1.507 & \\
\hline Osteopenia & 3.05 & 2.564 & 0.081 \\
\hline Osteoporosis & 6.11 & 3.635 & $<0.001$ \\
\hline
\end{tabular}


There were significant differences between the osteoporosis group and healthy group based on BDI score, favoring the osteoporosis group $(p<0.001)$, between the osteopenia group and the healthy group, favoring the osteopenia group $(p<0.001)$ and between the osteoporosis group and the osteopenia group, favoring the osteoporosis group $(p<0.001)$. The distribution of the presence of depression among the groups is presented in Table 3.

There were significant differences between the osteoporosis group and healthy group based on BAI score, favoring the osteoporosis group $(p<0.001)$ and between the osteopenia group and the healthy group, favoring the osteopenia $(p<0.001)$ (Table 3). There was no significant difference between the osteoporotic group and the osteopenia group, although osteoporotic group BAl score was higher $(p=0.106)$.

Incontinence severity, depression and anxiety scores distribution in groups are shown in Figure 1.

No correlations were determined between incontinence severity score and physical functioning, role limitations due to physical

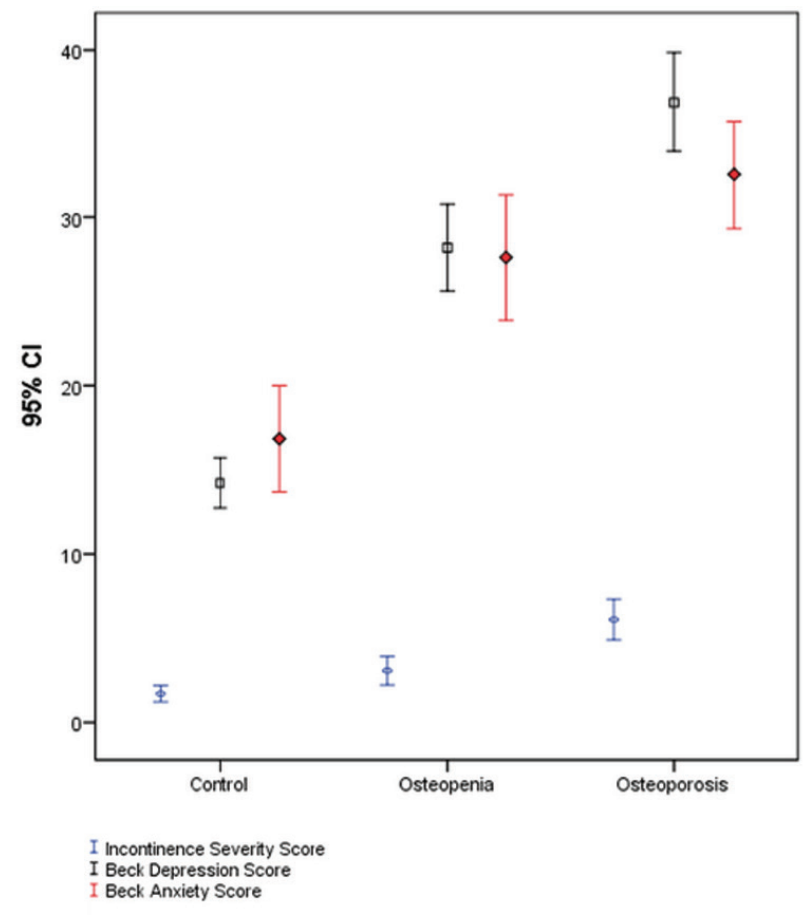

Figure 1. Incontinence severity, depression and anxiety scores distribution in groups

Cl: Confidence interval health, pain, general health, energy/fatigue, social functioning, role limitations due to emotional problems and emotional wellbeing subscales of quality of life (Table 4).

\section{Discussion}

In the present study, it was determined that there were significant differences between osteoporosis group and the other groups based on the incontinence severity score. The mechanisms through which osteoporosis increases UI risk are unknown, however a previous study demonstrated that spinal osteoporosis may lead to changes in the curvature of the spine, which is associated with pelvic organ prolapse (25). Osteoporosis-induced spinal compression fractures are likely to adversely affect the strength and endurance of the pelvic floor muscles, resulting in UI. Increased intraabdominal pressure due to compression fractures or changes in the curvature of the spine may also be another factor in the UI etiology (26). The fact that the osteoporosis group ISI score was significantly higher when compared to both the healthy group and the osteopenia group indicated that as BMD decreased, UI severity increased.

It was also found in the study that as the ISI score increased, BDI and BAI scores increased as well. UI affects mental health negatively by causing sexual dysfunction, limiting social activities, interpersonal relations and decreasing the selfesteem. It leads to anger, sadness, embarrassment, anxiety and depression (5). In previous studies, it was demonstrated that UI leads to embarrassment and decrease in self-confidence, dependence in spousal and professional relationships, serious obstacles in social life and is perceived as an anxious situation $(11,27)$. A social study conducted on 5701 50-69 years old females demonstrated that women with moderate UI had a $40 \%$ risk of developing depression, while women with severe UI had $80 \%$ risk (28). In another study, it was reported that anxiety and panic disorder, which is an anxiety disorder, is frequently associated with $\mathrm{UI}$ in females (29). Stach-Lempinen Bet et al. (30) reported that the prevalence of depression was associated with incontinence severity, social isolation, and quality of life. In the present study, it was determined that there were significant differences between the osteoporosis group and the other groups, and between the osteopenia group and the healthy group based on BDI and BAI scores. Although there was no significant difference between the osteoporotic group and the osteopenia group based on the BAI score, osteoporosis

Table 3. Depression and anxiety distribution in groups

\begin{tabular}{|l|l|l|l|l|}
\hline \multicolumn{2}{|c|}{} & $\begin{array}{l}\text { Normal } \\
\mathbf{n = 3 7}\end{array}$ & $\begin{array}{l}\text { Osteopenia } \\
\mathbf{n = 3 9}\end{array}$ & $\begin{array}{l}\text { Osteoporosis } \\
\mathbf{n = 3 7}\end{array}$ \\
\hline \multirow{3}{*}{ Depression } & Negative & 26 & 1 & 1 \\
\hline \multirow{3}{*}{ Anxiety } & Positive & 11 & 38 & 36 \\
\hline Then Beck Depression Inventory cut-off score is accepted as 17 & Negative & 13 & 1 & 0 \\
\cline { 2 - 5 } & Positive & 24 & 38 & 37 \\
\hline
\end{tabular}




\begin{tabular}{|c|c|c|c|c|c|c|c|}
\hline & \multicolumn{2}{|c|}{ Normal } & \multicolumn{2}{|c|}{ Osteopenia } & \multicolumn{2}{|c|}{ Osteoporosis } & \multirow[b]{2}{*}{$\mathbf{p}$} \\
\hline & Mean & Standard Deviation & Mean & Standard Deviation & Mean & Standard Deviation & \\
\hline PF & 45.30 & 23.80 & 44.30 & 25.33 & 52.50 & 21.80 & 0.810 \\
\hline RLPH & 33.00 & 41.16 & 41.50 & 44.50 & 56.25 & 51.54 & 0.427 \\
\hline Pain & 49.32 & 20.25 & 42.84 & 24.60 & 49.50 & 22.17 & 0.344 \\
\hline $\mathrm{GH}$ & 49.78 & 20.06 & 46.06 & 22.33 & 31.25 & 14.93 & 0.207 \\
\hline$E / F$ & 41.90 & 24.72 & 38.20 & 22.40 & 32.50 & 18.48 & 0.602 \\
\hline SF & 60.50 & 24.14 & 54.50 & 26.94 & 68.75 & 26.02 & 0.351 \\
\hline RLEH & 38.00 & 45.18 & 39.33 & 45.02 & 58.33 & 41.94 & 0.686 \\
\hline EWB & 60.08 & 22.94 & 60.40 & 22.02 & 55.00 & 17.40 & 0.897 \\
\hline
\end{tabular}

PF: Physical functioning, RLPH: Role limitations due to physical health, GH: General health, E/F: Energy/fatigue, SF: Social functioning, RLEH: Role limitations due to emotional problems, EWB: Emotional well-being

group score was higher. The correlation between low BMD and depression was shown in previous studies, and it was reported that BMD of patients diagnosed with depression was 15\% lower when compared to the controls (31). The correlation between depression and osteoporosis was considered to be due to their similar etiological causes. It is known that osteoporosis was associated with aging and as the individual ages, a decrease in gonadal function is observed. Seventy percent of women with $\mathrm{UI}$ associated the onset of symptoms with the onset of menopause (5). The low estrogen levels associated with menopause plays a triggering role for $\mathrm{UI}$ by weakening the collagen that forms the supportive tissue (32). There is also a correlation between depression and low estrogen and testosterone levels due to reduced gonadal function (33). In depression, the hypothalamus-pituitary-adrenal axis is inhibited, and cortisol release is increased. Similarly, blood cortisol levels increase in anxiety. Cortisol is a catabolic hormone that also promotes osteoporosis by increasing bone resorption. Factors such as limitation of movement, pain, urinary incontinence, dependence on others in daily life, social restrictions in osteoporosis patients may lead to an increase in depression and anxiety prevalence in osteoporosis, independent of the common etiology. Osteoporosis is a condition that mostly occurs with advanced age, and the most common psychiatric disorders associated with older age are depression and anxiety disorders. Thus, anxiety and depression may be considered as comorbid conditions in elderly osteoporosis patients. In the present study, it was found that the BDI and BAI scores of the osteoporotic and osteopenia groups were higher when compared to the healthy group, and osteoporotic group scores were higher than those of the osteopenia group and these findings were consistent with the above-mentioned information (34).

The findings reported by studies in the literature on the quality of life of patients with UI generally demonstrated that UI had a negative impact on quality of life. In a study conducted by Temml C et al., (35) $65.7 \%$ of the females and $58.3 \%$ of the males stated that UI had a negative impact on their quality of life and this effect was associated with the severity and frequency of UI and number of daily pads use. Akkus et al. (36) reported that UI had a negative impact on all aspects of quality of life. Abrams et al. (37) reported that UI had a negative effect on quality of life similar to chronic diseases such as Diabetes Mellitus. However, in a study by Karan et al. (38), Wagner's Quality of Life scale was applied to patients with UI, and the findings demonstrated a mild impairment in Quality of Life. They concluded that the quality of life is a subjective concept and is influenced by several factors and may differ even among races (39). Social studies reported that $20-30 \%$ of women had urinary incontinence, however only $7-12 \%$ perceived this as a problem (40), and most accepted it as a normal outcome of old age or pregnancy and deliveries (41). This difference between individuals and societies in quality of life assessment, or accepting the problem as a normal physiological process, may explain the differences between the findings of the studies that investigated the effects of UI on quality of life. In the present study, no correlation was determined between ISI score and quality of life subscales, consistent with the above findings. The present study has certain limitations. UI is more common in female population. In the present study, all participants were female. However, this may prevent generalization of the findings to both genders. Higher sample size would yield stronger study findings. In addition to health conditions, quality of life could also be affected by individual differences such as daily life conditions, interpersonal relationships, and the way individuals perceive and interpret stressors, which could not be excluded. Based on these factors, future studies with larger samples and that include participants of both genders may contribute further to the literature.

\section{Conclusion}

In the present study, it was observed that incontinence severity score increased as BMD decreased (from normal to osteoporosis). Depression and anxiety scores increased 
with increasing incontinence severity score. Although previous studies generally demonstrated that UI had a negative impact on quality of life, no correlation was determined between the ISI score and the quality of life subscale scores in the present study. UI is a common symptom among osteoporosis patients and $\mathrm{UI}$ is more severe in osteoporosis patients. However, since certain patients are embarrassed and certain others accept it as a normal physiological process, the applications for treatment are insufficient. Patients with osteoporosis exhibit high rates of depression and anxiety. UI itself leads to high depression and anxiety levels. When all factors are considered, questioning the presence of UI, depression and anxiety in the treatment and follow-up of osteoporosis patients would lead to correct treatment and increase the treatment success rate.

\section{Ethics}

Ethics Committee Approval: The study was approved by the ethics committee of Kahramanmaraş Sütçü Imam University Faculty of Medicine (protocol no:142/06 date: 05.05.2019).

Informed Consent: Informed consents from patient were taken.

Peer-review: Externally and internally peer-reviewed.

\section{Authorship Contributions}

Surgical and Medical Practices: E.B., S.B., Concept: E.B., Design: E.B., S.B., Data Collection or Processing: E.B., Analysis or Interpretation: E.B., S.B., Literature Search: E.B., S.B., Writing: E.B., S.B.

Conflict of Interest: The authors declare that there are no conflicts of interest.

Financial Disclosure: The authors declared that this study received no financial support.

\section{References}

1. Melton L, Akyol Y, Durmuş D. Osteoporozun epidemiyolojisi ve sınıflandırıması. Romatoloji içinde: Hochberg MC, Silman AJ, Smolen JS, Weintblatt ME, Weismann MH, editörler. Arasıl T, Duruöz T, Dinçer K, Uğurlu H, Şenel K. Veri Medikal Yayıncılık Rotatıp Kitabevi, Ankara, 2011. p. 1917-23.

2. Vilela P, Nunes T. Osteoporosis. Neuroradiology 2011;S185-9.

3. Mitchell BD, Yerges-Armstrong LM. The genetics of bone loss: challenges and prospects. J Clin Endocrinol Metab 2011;96:125868.

4. Charalambous S, Trantafylıdıs A. Impact of urinary incontinence on quality of life. Pelviperineology 2009;28:51-53.

5. Cook K, Sobeski LM. Urinary incontinence in the older adult. PSAP Special Populations 2013;3-19.

6. Jackson RA, Vittinghoff E, Kanaya AM, Miles TP, Resnick HE, Kritchevsky SB, et al. Urinary incontinence in elderly women: findings from the Health, Aging, and Body Composition Study. Obstet Gynecol 2004;104:301-7.

7. Sran MM. Prevalence of urinary incontinence in women with osteoporosis. J Obstet Gynaecol Can 2009;31:434-9.

8. Hannestad YS, Rortveit G, Sandvik H, Hunskaar S; Norwegian EPINCONT study. Epidemiology of Incontinence in the County of Nord-Trøndelag. A community-based epidemiological survey of female urinary incontinence: the Norwegian epıncont study. Epidemiology of Incontinence in the County of Nord-Trondeløg. J Clin Epidemiol 2000;53:1150-7.

9. Wetle T, Scherr P, Branch LG, Resnick NM, Harris T, Evans D, et al. Difficulty with holding urine among older persons in a geographically defined community: prevalence and correlates. Journal of the American Geriatrics Society 1995;43:349-355.

10. Loge DLC, Sullivan K, Pinkney R, Marquis P, Roux C, Meunier PJ. Cross-cultural validation and analysis of responsiveness of the QUALIOST: QUAlity of Life questionnaire In OSTeoporosis. Health Qual Life Outcomes 2005;3:69.

11. Goldacre MJ, Abisgold JD, Yeates DG, Voss S, Seagroatt V. Selfharm and depression in women with urinary incontinence: a record-linkage study. BJU Int 2007;99:601-5.

12. Williams K. Stress urinary incontinence: treatment and support. Nurs Stand 2004;18:45-52.

13. Vahia VN. Diagnostic and statistical manual of mental disorders 5 : A quick glance. Indian J Psychiatry 2013;55:220-223.

14. Kanis JA, Glüer CC. An update on the diagnosis and assessment of osteoporosis with densitometry. Committee of Scientific Advisors, International Osteoporosis Foundation. Osteoporos Int 2000;11:192-202.

15. Riis P. Perspectives on the Fifth Revision of the Declaration of Helsinki. JAMA 2000;284:3045-3046.

16. Sandvik H, Espuna M, Hunskaar S. Validity of the incontinence severity index: comparison with pad-weighing tests. Int Urogynecol J Pelvic Floor Dysfunct 2006;17:520-4.

17. Hazar HU, Şirin A. Inkontinans siddet indeksinin geçerlik ve güvenirliği çalışması. ADÜ Tıp Fakültesi Dergisi 2008;9:5-8.

18. Beck AT, Ward CH, Mendelson M, Mock J, Erbaugh J. An inventory for measuring depression. Archives of general psychiatry 1961:4:561-571.

19. Hisli N. Effect of patients' evaluation of group behavior on therapy outcome. International journal of group psychotherapy 1987;37:119-24.

20. Beck AT, Epstein N, Brown G, Steer RA. An inventory for measuring clinical anxiety: psychometric properties. Journal of consulting and clinical psychology 1988;56:893-7.

21. Ulusoy $M$, Sahin NH, Erkmen $H$. Turkish version of the beck anxiety inventory: psychometric properties. J Cogn Psychother 1998;12:163-72.

22. Ware JE, Sherbourne CD. The MOS 36-item short-form health survey (SF-36): I. Conceptual framework and item selection. Medical care 1992;473-483.

23. Koçyiğit H, Aydemir Ö, Fişek G, Ölmez N, Memiş A. Form-36 (KF-36)'nın Türkçe versiyonunun güvenilirliği ve geçerliliği. llaç ve tedavi dergisi 1999;12:102-6.

24. Aydemir Ö. Konsültasyon-Liyezon psikiyatrisinde yaşam kalitesi ölçümü: Kısa Form-36 (SF-36). Psikiyatri Psikoloji Psikofarmakoloji (3P) Dergisi 1999;14-22.

25. Mattox TF, Lucente V, McIntyre P, Miklos JR, Tomezsko J. Abnormal spinal curvature and its relationship to pelvic organ prolapse. Am J Obstet Gynecol 2000;183:1381-4.

26. Sran M, Mercier J, Wilson P, Lieblich P, Dumoulin C. Physical therapy for urinary incontinence in postmenopausal women with osteoporosis or low bone density: a randomized controlled trial. Menopause 2016;23:286-93.

27. Özerdogan N, Beji NK, Yalçın Ö. Urinary incontinence: its prevalence, risk factors and effects on the quality of life of women living in a region of Turkey. Gynecologic and obstetric investigation 2004;58:145-50.

28. Nygaard I, Turvey C, Burns TL, Crischilles E, Wallace R. Urinary incontinence and depression in middle-aged United States women. Obstet Gynecol 2003;101:149-56.

29. Melville JL, Walker E, Katon W, Lentz G, Miller J, Fenner D. Prevalence of comorbid psychiatric illness and its impact on symptom perception, quality of life, and functional status in women with urinary incontinence. Am J Obstet Gynecol 2002;187:80-7.

30. Stach-Lempinen B, Hakala AL, Laippala P, Lehtinen K, Metsänoja R, Kujansuu E. Severe depression determines quality of life in urinary incontinent women. Neurourol Urodyn 2003;22: 563-8.

31. Schweiger U, Deuschle M, Körner A, Lammers CH, Schmider J, Gotthardt $U$, et al. Low lumbar bone mineral density in patients with major depression. Am J Psychiatry 1994;151:1691-3.

32. Miller K, Richardson DA, Siegel SW, Karram MM, Blackwood NB, Sand PK. Pelvic floor electrical stimulation for genuine 
stress incontinence: who will benefit and when? International Urogynecology Journal 1998;9:265-270.

33. Khosla S, Melton LJ, Atkinson EJ, O'Fallon WM, Klee GG, Riggs $\mathrm{BL}$. Relationship of serum sex steroid levels and bone turnover markers with bone mineral density in men and women: a key role for bioavailable estrogen. J Clin Endocrinol Metab 1998;83:226674

34. Akarirmak U. Depression and osteoporosis. Turkish Journal of Osteoporosis 2012;18:63-68.

35. Temml C, Haidinger G, Schmidbauer J, Schatzl G, Madersbacher S. Urinary incontinence in both sexes: prevalence rates and impact on quality of life and sexual life. Neurourol Urodyn 2000;19:25971.

36. Akkus Y, Pınar G. Evaluation of the prevalence, type, severity, and risk factors of urinary incontinence and its impact on quality of life among women in Turkey. Int Urogynecol J 2016;27:887-93.

37. Abrams P, Kelleher CJ, Kerr LA, Rogers RG. Overactive bladder significantly affects quality of life. Am J Manag Care 2000;6:580590
38. Karan A, Aksaç B, Ayyıldız H, Işıkoğlu M, Yalçın O, Eskiyurt N. Quality of life and its relation with objective assessment parameters in urinary incontinent patients. Geriatri 2000;3:102-6.

39. Patrick DL, Martin ML, Bushnell DM, Marquis $P$, Andrejasich CM, Buesching DP. Cultural adaptation of a quality-of-life measure for urinary incontinence. European urology 1999;36:427-435.

40. Kök G, Şenel N, Akyüz A. GATA Jinekoloji Polikliniğine başvuran 20 yaş üstü kadınların üriner inkontinans açısından farkındalık durumlarının değerlendirilmesi. Gülhane Tıp Dergisi 2006;48:132136.

41. Kılıçarslan $H$, Vuruşkan $H$, Doğan HS. Kadınlarda tüm stres üriner inkontinans tedavisinde otolog rektus fasyası kullanılarak yapılan pubovajinal sling. Uludağ Üniversitesi Tıp Fakültesi Dergisi 2007;33:11-14 